\title{
Antibacterial chemical defenses in Hawaiian corals provide possible protection from disease
}

\author{
Deborah J. Gochfeld ${ }^{1, *}$, Greta S. Aeby ${ }^{2}$ \\ ${ }^{1}$ National Center for Natural Products Research, PO Box 1848, University of Mississippi, University, Mississippi 38677, USA \\ ${ }^{2}$ Hawaii Institute of Marine Biology, PO Box 1346, Kaneohe, Hawaii 96744, USA
}

\begin{abstract}
Diseases of marine organisms, and corals in particular, have been reported with increasing frequency over the past 3 decades. Although little is known about resistance to disease in corals, a potential mechanism of defense is the production of antimicrobial compounds that protect corals from microbial pathogens. We assessed the antibacterial activity of crude aqueous extracts from 3 common Hawaiian reef corals, Montipora capitata, Porites lobata, and Pocillopora meandrina, against 9 strains of bacteria. The bacteria selected included known coral pathogens, potential marine pathogens found in human waste, and bacteria previously identified from the surfaces of Hawaiian corals. Extracts from all 3 coral species exhibited high levels of antibacterial activity. Overall, 54.3\% of assays resulted in bacterial growth inhibition. In addition, 9.9\% of extracts stimulated the growth of certain bacteria. Although levels of overall antibacterial activity did not differ significantly among coral species (ranging from $40.7 \%$ of assays for $P$. meandrina to $63.0 \%$ of assays for $M$. capitata), the 3 species exhibited a high degree of selectivity as demonstrated by significant variability in their effects toward specific bacteria. Extracts also exhibited intraspecific variability, both within and between sites, and significant site-by-species interactions were observed against 6 of 9 bacterial strains. In $M$. capitata, healthy corals had significantly higher levels of antibacterial activity than those affected by Montipora White Syndrome, and affected tissues had significantly higher levels of antibacterial activity than unaffected tissues. Variability in antibacterial activity of Hawaiian corals may, in part, explain differential susceptibility to disease at the colony, species, or population level.
\end{abstract}

KEY WORDS: Antibacterial · Coral disease · Resistance · Inducible defenses • Montipora · Pocillopora $\cdot$ Porites

Resale or republication not permitted without written consent of the publisher

\section{INTRODUCTION}

Coral disease has emerged as a serious threat to coral reefs worldwide and is a major cause of reef deterioration (Rosenberg \& Loya 2004, Weil et al. 2006). The numbers of diseases and coral species affected, as well as the geographic distribution of diseases, have all increased dramatically within the last decade (Sutherland et al. 2004, Weil 2004). Epizootics of coral disease have resulted in significant losses of coral cover in the Caribbean, and disease is now also emerging as a problem on reefs throughout the Indo-Pacific. For example, the Australian Institute of Marine Science Long Term Monitoring Program documented a 22- to 150-fold increase in White Syndrome over a 5 yr period in some areas of the Great Barrier Reef (Willis et al. 2004). Increased anthropogenic stress in near-shore environments and environmental conditions associated with global climate change have all been implicated as contributing to increased incidence of disease (Harvell et al. 1999, Barber et al. 2001), and the need to understand disease susceptibility in corals is increasingly important.

Corals have a suite of highly efficient defense mechanisms to rid themselves of sediment, settling organisms, and potential pathogens, including the production, release, and biochemical properties of mucus, phagocytic cells that can engulf and destroy micro- 
organisms, and antimicrobial chemical defenses (Mullen et al. 2004, Sutherland et al. 2004, Ward et al. 2007). Differences in types and levels of defense vary among families, genera, and species and even at the level of the individual colony (Mullen et al. 2004, Gochfeld et al. 2006). These differences might enable particular populations, species, or genotypes to have an advantage over others in resisting invasion by pathogens. To date, a few studies have specifically examined mechanisms of defense against pathogens (e.g. Dube et al. 2002, Ellner et al. 2007, Mydlarz \& Harvell 2007), yet elucidating mechanisms of disease resistance in corals is essential to our understanding of patterns of disease prevalence and virulence.

Antimicrobial chemical defenses are well documented in marine invertebrates. Extracts from many Caribbean gorgonian species have antimicrobial activity (Jensen et al. 1996), and several inhibit spore germination of Aspergillus sydowii, the fungal pathogen that causes aspergillosis in sea fans (Kim et al. 2000a,b). Differences in levels of antifungal chemical defenses among sea fans have been linked to speciesspecific susceptibility to aspergillosis (Mullen et al. 2004). Scleractinian corals have also been found to produce chemical defenses, although these are less well studied than those in soft-bodied invertebrates. Gochfeld (1997) demonstrated chemical defenses against predatory fish in 2 species of Hawaiian corals, and in one of the earliest studies on coral chemical defenses, Gunthorpe \& Cameron (1990) documented antibacterial activity in 37 of 55 species of Australian corals. Likewise, Koh (1997) found that extracts from 100 Australian coral species inhibited growth of a marine cyanobacterium, and extracts from 8 species inhibited growth of marine bacteria. Caribbean corals also exhibit selective antibacterial activity against ecologically relevant marine bacteria (Gochfeld et al. 2006). In addition to whole-tissue extracts, the mucus layer and its associated microbial flora also possess antibacterial activity and may act as the first line of defense against invading pathogens (Ritchie 2006). These and other studies have demonstrated that antimicrobial activity varies at the colony, species, and population levels, and exhibits a high degree of selectivity for specific microorganisms.

In Hawaii, 17 coral diseases have been reported from the 4 major genera of reef-building corals (Porites, Montipora, Pocillopora, Acropora; Friedlander et al. 2005, Aeby 2006). Differences in type, occurrence, and prevalence of diseases exist between islands within the archipelago, sites within islands, and among coral genera (Friedlander et al. 2005, Aeby 2006). For example, in the Northwestern Hawaiian Islands, 4 diseases were described from Porites, compared to only 1 disease in Pocillopora (Aeby 2006). As seen elsewhere in the world (Gochfeld et al. 2006), differential susceptibility within species is also observed on Hawaiian reefs, with infected colonies adjacent to apparently healthy neighbors. Differences in levels of defenses within and between coral species and colonies may help explain patterns of disease occurrence on reefs. Here we examined chemical resistance as a potential mechanism of immune function for corals against pathogenic bacterial infections. We investigated 3 common scleractinian coral species (Montipora capitata, Porites lobata, Pocillopora meandrina) found on the reefs of Oahu, Hawaii, USA, to determine whether they exhibited antibacterial activity, and characterized differences in activity among species and between populations within a species. In addition, we used Montipora White Syndrome (MWS), an emerging infectious disease affecting M. capitata in Kaneohe Bay, Oahu, as a model system, to compare antibacterial activity between diseased and healthy coral colonies.

\section{MATERIALS AND METHODS}

Coral species and study sites. Small fragments from healthy colonies of Montipora capitata, Porites lobata, and Pocillopora meandrina were sampled from each of 3 sites on Oahu: Kaneohe Bay $\left(21^{\circ} 27.25^{\prime} \mathrm{N}, 157^{\circ} 46.551^{\prime} \mathrm{W}\right)$, Waianae $\left(21^{\circ} 26.76^{\prime} \mathrm{N}\right.$, $\left.158^{\circ} 11.953^{\prime} \mathrm{W}\right)$, and Maile Beach $\left(21^{\circ} 24.91^{\prime} \mathrm{N}\right.$, $158^{\circ} 11.050^{\prime} \mathrm{W}$ ). Individual branches or small pieces (ca. $5 \times 2 \mathrm{~cm}$ ) were collected by divers using SCUBA and maintained in seawater until return to the laboratory where they were immediately frozen. Frozen samples were subsequently transported to the University of Mississippi for processing.

Preparation of extracts. Samples were placed in covered beakers and extracted in Millipore ${ }^{\circledR}$ water, which was replaced daily for $3 \mathrm{~d}$. Aqueous extracts were used because previous work on Hawaiian coral chemical defenses found that polar extracts had higher levels of ecological activity than nonpolar extracts (Gochfeld 1997). Extracts were filtered, lyophilized, and weighed.

We tested extracts at concentrations approximating those naturally found in the coral tissues. To determine the volumetric concentrations of extracts, the surface area of each piece of coral was calculated using the wax technique (Gochfeld 1991). Tissue volume was determined by multiplying surface area by tissue depth measured from replicate decalcified pieces of each coral species. Montipora capitata did not lend itself to the wax method since the wax absorbed into its perforate skeleton. Instead, digital photographs of the $M$. capitata pieces were imported into ImagePro ${ }^{\circledR}$ software and their surface areas calculated. This was mul- 
Table 1. Bacterial strains used in coral antibacterial assays

\begin{tabular}{|c|c|c|c|c|}
\hline Bacterial strain & $\begin{array}{l}\text { Known coral } \\
\text { pathogen }\end{array}$ & $\begin{array}{l}\text { Potential marine pathogen } \\
\text { from human waste }\end{array}$ & $\begin{array}{c}\text { Hawaiian coral } \\
\text { associate }\end{array}$ & Source \\
\hline Aurantimonas coralicida & White Plague type Il & & & Denner et al. (2003) \\
\hline Clostridium perfringens & & $\mathrm{X}$ & & Lipp et al. (2002) \\
\hline Klebsiella pneumoniae & & & Porites lobata & Lewis (2005) \\
\hline Pseudomonas nautica & & & Porites lobata & Lewis (2005) \\
\hline Serratia marcescens & White Pox & $\mathrm{X}$ & & Patterson et al. (2002) \\
\hline Vibrio agarivorans & & & not specified & Lewis (2005) \\
\hline Vibrio coralliilyticus & Coral Tissue Lysis & & & Ben-Haim et al. (2003) \\
\hline Vibrio shiloi & Coral Bleaching & & not specified & $\begin{array}{l}\text { Kushmaro et al. (2001), } \\
\text { Lewis (2005) }\end{array}$ \\
\hline Yersinia enterocolitica & & $\mathrm{X}$ & Montipora capitata & $\begin{array}{l}\text { Weagant \& Kaysner (1983), } \\
\text { Lewis (2005) }\end{array}$ \\
\hline
\end{tabular}

tiplied by the thickness of each piece and the depth of the decalcified coral tissue. Extract concentrations were determined as $\mathrm{g}$ dried extract $\mathrm{ml}^{-1}$ of coral tissue. Extracts were re-suspended to these concentrations in Millipore ${ }^{\circledR}$ water for use in bacterial growth assays.

Pathogens. To date, specific bacterial pathogens responsible for Hawaiian coral diseases have not been identified. Thus, the 9 strains used for our antibacterial assays were selected as model systems to represent a range of potential bacterial pathogens from the marine environment, including known coral pathogens, human enteric bacteria that have the potential to enter near-shore waters and can survive in the marine environment, and bacteria related to those that have been isolated from the surfaces of Hawaiian corals (Table 1). Bacterial stocks were purchased from the American Type Culture Collection (ATCC) and the Deutsche Sammlung von Mikroorganismen und Zellkulturen (DSMZ, German Collection of Microorganisms and Cell Cultures) and cultured in media and conditions as specified.

Bioassays. Most previous studies of this nature (e.g. Gunthorpe \& Cameron 1990, Jensen et al. 1996, Koh 1997, Kelly et al. 2005, Kelman et al. 2006) have used the disc-diffusion assay. However, the disc-diffusion assay requires unnecessarily large quantities of extract. Instead, we employed an assay that measured inhibition of bacterial growth in smaller format (96 well plates), requiring collection of smaller pieces of coral. Following the growth assay, bacteria from wells containing inhibitory extracts were then tested in an assay to assess whether the activity was cytostatic (growth inhibition) or cytotoxic (cell mortality).

Growth inhibition assay: Assays were run in triplicate in 96 well plates. Plates contained 3 wells of bacteria + each extract $(n=5$ replicate corals of 3 species at each of 3 sites), along with the following controls: bacteria only, bacteria + ciprofloxacin, media only, and extract solution to control for the coloration of extracts.
Aqueous extracts were dissolved in Millipore ${ }^{\circledR}$ water. Twenty-four hour bacterial cultures in exponential growth were diluted to optical density (OD) 600, and $100 \mu \mathrm{l}$ were added to each well. We added $10 \mu \mathrm{l}$ of extract or of a $1 \mathrm{mg} \mathrm{ml}^{-1}$ ciprofloxacin solution to the experimental or control wells, respectively. Wells were mixed by carefully pipetting their contents, and an initial reading (time 0) of OD was made on a BioTek Synergy $^{\mathrm{TM}}$ HT Multi-Detection Microplate Reader. Plates were then covered with foil and incubated on a shaker for 5 (Klebsiella pneumoniae, Serratia marcescens, Yersinia enterocolitica), 7 (Clostridium perfringens), or $24 \mathrm{~h}$ (Aurantimonas coralicida, Pseudomonas nautica, Vibrio agarivorans, V. coralliilyticus, V. shiloi), depending upon the growth rate of each bacterial strain. For $5 \mathrm{~h}$ assays, readings were made every hour; for 7 and $24 \mathrm{~h}$ assays, an initial and final reading were made. Prior to each reading, wells were mixed again to resuspend any settled material. Clostridium perfringens is an anaerobe, and these assays were incubated in GasPak ${ }^{\mathrm{TM}}$ EZ chambers (Becton-Dickinson) prior to reading.

Cytotoxicity assay: Following the assays, growth curves were graphed (Fig. 1), and samples for which the slope of the growth curve was lower than that for the bacteria-only control were plated onto the relevant solid media. After $24 \mathrm{~h}$ of incubation, the plate was visually examined to determine whether the bacteria had grown (indicating a cytostatic effect of the extract in the growth inhibition assay) or not (indicating a potential cytotoxic effect in the growth inhibition assay).

Comparison between healthy and diseased conspecifics. To assess whether coral condition is related to antibacterial activity, small fragments of Montipora capitata from healthy and affected tissues on colonies exhibiting signs of MWS, along with pieces from an apparently healthy neighboring colony (control; $\mathrm{n}=5$ ) were collected from a single reef in Kaneohe Bay. MWS manifests as exposed white skeleton adjacent to 
healthy tissue, with the recently dead area of the colony rapidly colonized by algae. The samples of affected tissues were collected to encompass the exposed leading edge and an equivalent amount of
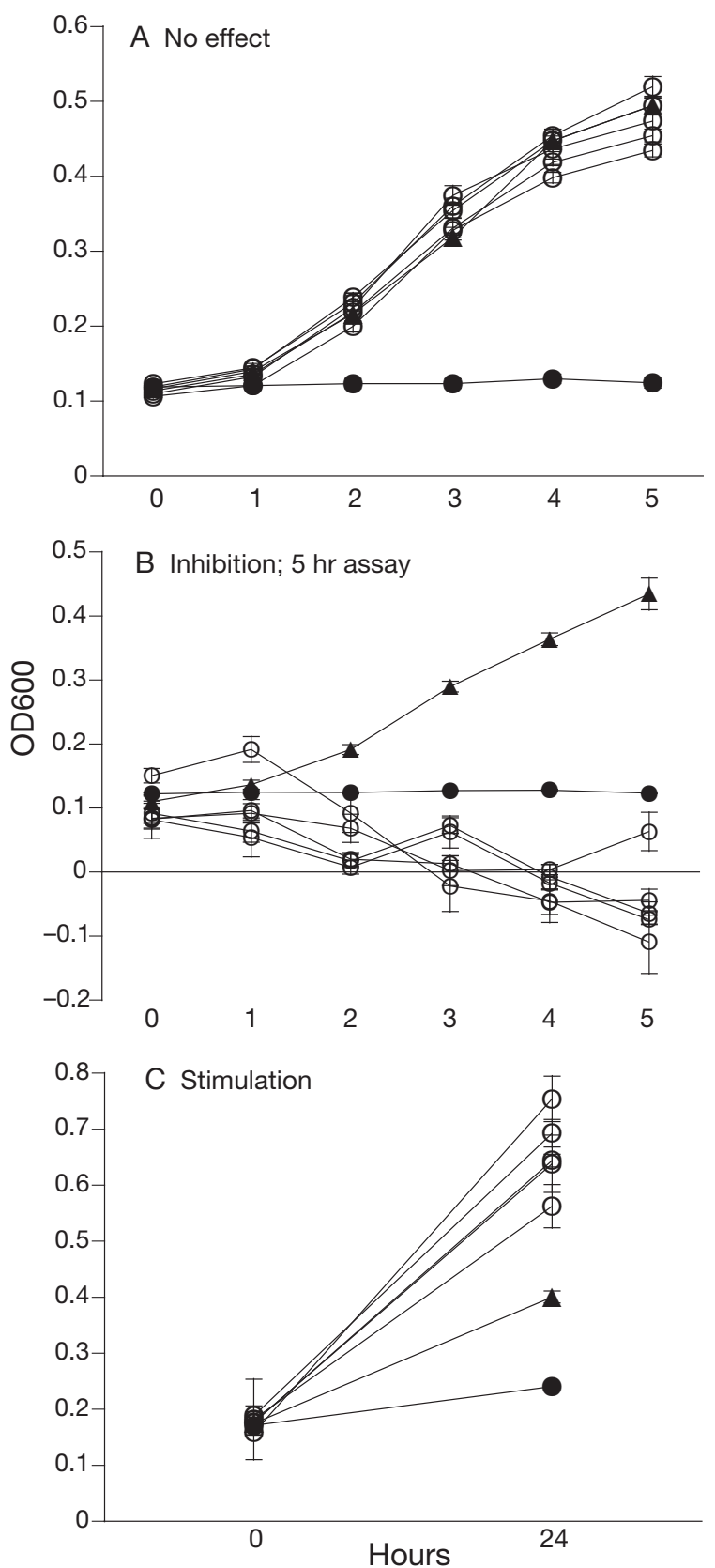

Fig. 1. Representative growth curves from the bacterial growth assays. These data represent all possible interactions between coral extracts and bacteria. Data are means $\pm \mathrm{SE}, \mathrm{n}=$ 3. $\mathbf{\Lambda}$, bacteria-only controls; $\bullet$, bacteria with ciprofloxacin; $O$, bacteria with extracts from 5 coral colonies. (A) Porites lobata extracts with no effect on Yersinia enterocolitica. (B) Montipora capitata extracts with inhibitory effect on Serratia marcescens. (C) Pocillopora meandrina extracts with stimulatory effects on Vibrio shiloi adjacent healthy tissue. Healthy samples from affected colonies were collected at the opposite side of the colony from the affected region, typically 0.5 to $1 \mathrm{~m}$ away. Extractions were performed, and extracts were tested against all bacteria except Clostridium perfringens in bacterial growth assays, as described above.

Data analysis. To compare the growth curves from assays performed on different plates and at different times, we controlled for natural bacterial growth in each assay by subtracting the mean optical density of the 3 control wells (media + bacteria) from the optical density of each well containing an extract in that assay. In addition, the mean optical density of the 2 wells containing each extract solution was also subtracted from those wells to control for the dark color of the extracts. In all assays, the ciprofloxacin control had a significant inhibitory effect on bacterial growth (Fig. 1), but these data were not used in any further analyses.

To determine whether the extracts from each species-site combination exhibited significant activity against the 9 bacterial strains, the mean slope of the triplicate growth curves for each extract against each bacterial strain was calculated, and $t$-tests were used to determine whether these mean slopes differed significantly from 0 . To compare levels of antibacterial activity among coral species and sites, 2-way analyses of variance (ANOVAs) were performed on the mean slopes, with site and species as fixed factors, followed by Tukey's pair-wise comparisons on site and species.

To determine whether colonies of Montipora capitata affected by MWS ('diseased') have different levels of antibacterial activity than healthy neighboring colonies, we compared the mean slopes of the bacterial growth curves for extracts from healthy tissues on the diseased corals to those from healthy neighboring colonies (controls) using paired $t$-tests. Paired $t$-tests were also used to compare the activity of extracts from the affected tissues on the diseased colonies of M. capitata to healthy tissues from the same colonies.

\section{RESULTS}

Representative examples of growth curves from the bacterial growth assays are shown in Fig. 1. Overall, out of 81 assays ( 3 coral species from 3 sites tested against 9 bacterial strains), 8 (9.9\%) exhibited significant stimulatory and 44 (54.3\%) exhibited significant inhibitory activity. Antibacterial activity was observed in 63.0, 59.3 and $40.7 \%$ of assays using Montipora capitata, Porites lobata, and Pocillopora meandrina extracts, respectively.

Fig. 2 plots the slopes of the growth curves for each coral species-site combination against each bacterial strain. Although all 3 coral species exhibited antibacte- 

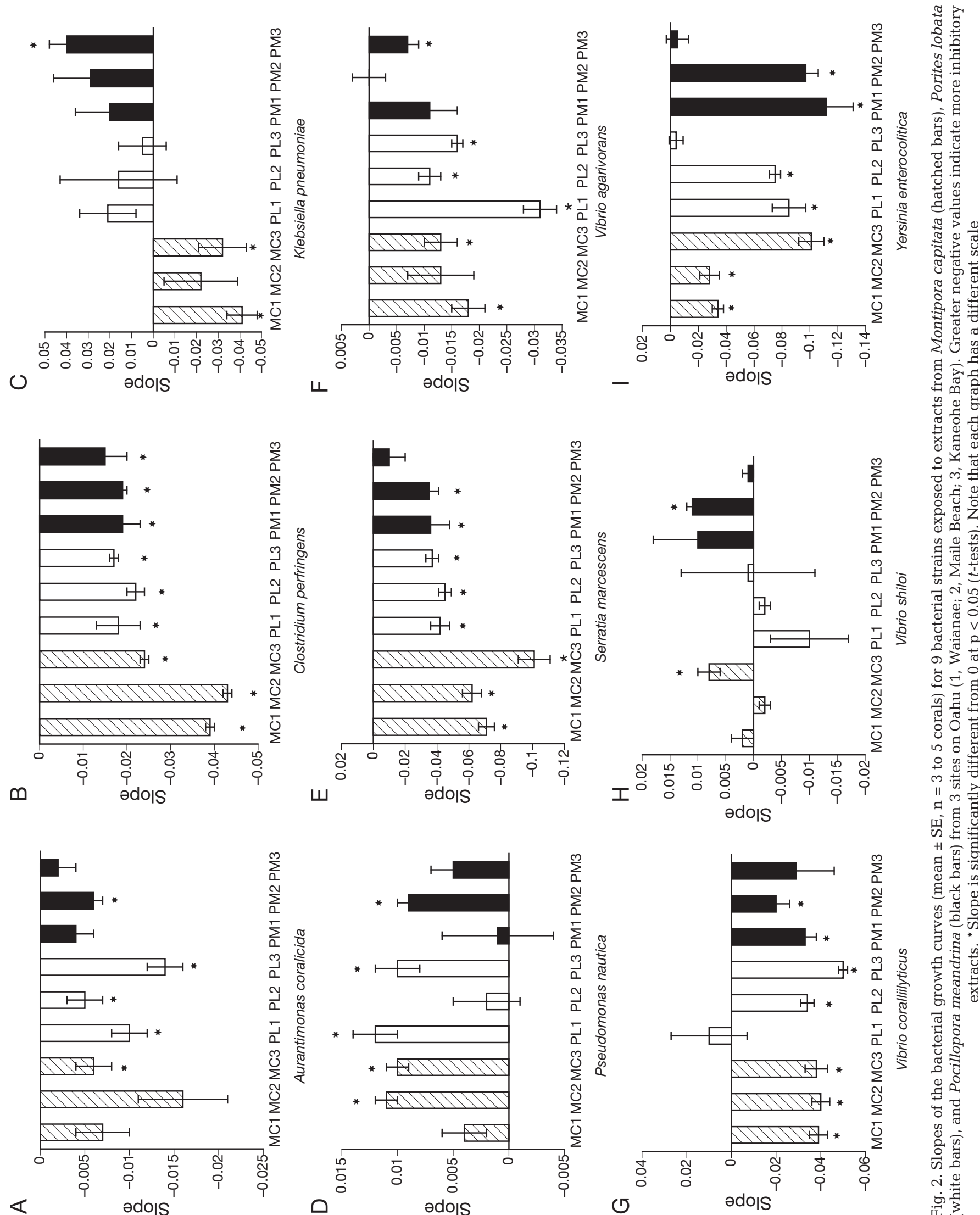


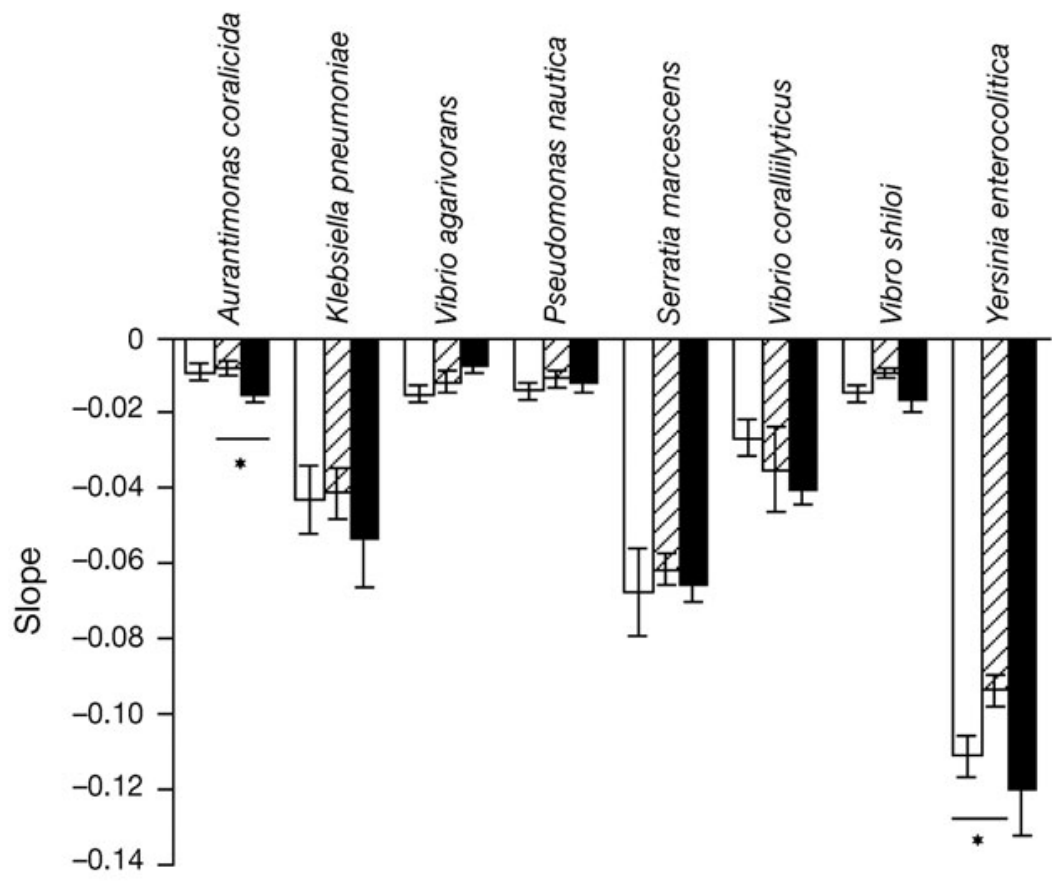

Fig. 3. Comparison of slopes of the bacterial growth assays (mean $\pm S E, n=5$ corals) for 8 bacterial strains exposed to extracts from healthy tissue from Montipora capitata colonies affected by Montipora White Syndrome (MWS), diseased tissue from these colonies, and nearest neighbor healthy control conspecifics. Paired $t$-tests compared (1) healthy and diseased tissues from MWS-affected colonies and (2) healthy tissues on MWS-affected colonies to healthy control colonies. Greater negative values indicate more inhibitory extracts. ${ }^{*}$ Slopes are significantly different in pair-wise comparisons at $\mathrm{p}<0.05$ (paired $t$-tests). White bars, nearest neighbor healthy control; hatched bars, healthy tissue on diseased colony; black bars, diseased tissue

fringens, Klebsiella pneumoniae, and V. agarivorans. Pair-wise comparisons indicated that Montipora capitata extracts were more inhibitory than those of the other 2 coral species, and that extracts from Kaneohe Bay were less inhibitory than those from the other 2 sites. Intraspecific (among colony) variability for each speciessite combination can be seen in the relatively large error bars in some of the assays (Fig. 2), but this was not analyzed statistically.

Almost all of the inhibitory extracts exhibited cytostatic activity. Only 5 extracts resulted in bacteria not growing when plated onto solid media, including 3 from Pocillopora meandrina, 1 from Porites lobata, and 1 from Montipora capitata.

Extracts from healthy (control) colonies of Montipora capitata exhibited significantly greater antibacterial activity against Yersinia enterocolitica than did healthy tissues on diseased colonies affected by MWS (Fig. 3; paired $t$-test, $\mathrm{p}=0.04$ ), and there was a trend toward greater activity in the control colonies against Vibrio shiloi $(\mathrm{p}=0.07)$. Extracts from diseased tissues on affected colonies exhibited significantly higher levels of anti-

rial activity, they exhibited a high degree of selectivity against different bacterial strains (Fig. 2). For example, extracts from all 3 coral species inhibited growth of Aurantimonas coralicida, Clostridium perfringens, Serratia marcescens, Vibrio agarivorans, V. coralliilyticus, and Yersinia enterocolitica. However, Montipora capitata exhibited significant inhibitory activity against Klebsiella pneumoniae, whereas Porites lobata extracts had no effect and Pocillopora meandrina extracts had a significant stimulatory effect.

Antibacterial activity varied significantly by coral species and site for certain bacterial strains (Fig. 2). The strains of bacteria affected by each coral species differed significantly (2-way ANOVA, p < 0.05) with the exception of Pseudomonas nautica and Vibrio coralliilyticus. All 3 coral species stimulated the growth of $P$. nautica and inhibited the growth of $V$. coralliilyticus. There were also significant differences in antibacterial activity among sites for some of the bacterial strains (Clostridium perfringens, V. agarivorans, and Yersinia enterocolitica; 2-way ANOVA, p < 0.05). Significant species $\times$ site interactions $(2$-way ANOVA, $\mathrm{p}<$ 0.05 ) were observed against all bacteria except $C$. per- bacterial activity against Aurantimonas coralicida than did healthy tissues from the same colonies (Fig. 3; paired $t$-test, $\mathrm{p}=0.003$ ), and there was a trend toward higher activity against $Y$. enterocolitica in the diseased tissues as well $(\mathrm{p}=0.09)$.

\section{DISCUSSION}

The presence of antimicrobial chemical defenses has been proposed as a potential mechanism of disease resistance in scleractinian corals (Mullen et al. 2004, Sutherland et al. 2004), but few studies have tested this. In the present study, we found that 3 of the dominant coral species on Hawaiian reefs produce antibacterial chemical defenses against a variety of bacterial strains. The observed antibacterial activity varied at the coral colony, population, and species levels, and the activity was highly selective against the different bacterial strains, rather than broad-spectrum in nature. Thus, differences in levels or types of antibacterial chemical defenses may represent a mechanism by which variability in resistance or susceptibility to 
pathogens might be realized and may help explain patterns of disease prevalence observed in the field.

Overall, $54.3 \%$ of extracts inhibited bacterial growth. There were no significant differences in overall levels of antibacterial activity among the 3 coral species $(40.7 \%$ to $63.0 \%$ of assays; Fig. 2); however, Pocillopora meandrina extracts were less active than the other 2 species, inhibiting growth significantly in only 11 out of 27 assays as compared to 16 or 17 out of 27 assays for Montipora capitata and Porites lobata, respectively. This was surprising, as Pocillopora exhibits lower levels of disease than other coral genera in Hawaii. In the Northwestern Hawaiian Islands, Aeby (2006) found that Pocillopora had the lowest frequency of disease occurrence ( $1.4 \%$ of sites surveyed) and the lowest overall disease prevalence $(0.016 \%$ of colonies surveyed). It may be that Pocillopora uses other defensive mechanisms against disease, and/or its antibacterial defenses may be more selective toward pathogenic bacteria specifically affecting Hawaiian corals.

Interspecific differences in antibacterial activity were evident in their effects on different bacterial strains. Selectivity is a hallmark of antimicrobial activity in corals (Gunthorpe \& Cameron 1990, Marquis et al. 2005, Gochfeld et al. 2006). This selectivity is important, as it would not be adaptive to inhibit the growth of all bacteria since corals do possess a naturally associated microbial community, which is believed to play a role in the healthy functioning of the coral holobiont (Ritchie 2006). Instead, selection to inhibit only those organisms that might be detrimental to coral health would be favored. Consistent with this, we found that several of the extracts stimulated bacterial growth. For example, all extracts stimulated the growth of Pseudomonas nautica to some degree, and all extracts from Porites lobata and Pocillopora meandrina stimulated the growth of Klebsiella pneumoniae, whereas Montipora capitata extracts were inhibitory (Fig. 2D,C). P. nautica and Klebsiella sp. have been isolated from the surfaces of $P$. lobata in Hawaii (Lewis 2005), and although their functions in Hawaiian corals are unknown, they could play a role in the health of the coral holobiont. These findings are consistent with the fact that the normal microbial community found on corals is species-specific (Rohwer et al. 2001, 2002). One proposed role of coralassociated bacteria is their own production of antimicrobial compounds that may protect the coral from pathogens (Ritchie 2006). These natural microbial communities preferentially use carbon sources in the mucus for their own metabolism (Ritchie \& Smith 1995). Coral extracts are composed of a diversity of complex organic metabolites that may also serve as highly nutritional carbon sources for microorganisms and may be another mechanism by which corals acquire and maintain their naturally associated microbial communities.
Population-level (site-specific) variability in antibacterial activity was also apparent in these coral species. Sites did not exhibit significant differences in levels of overall antibacterial activity (48.1 to $55.6 \%$ of assays; Fig. 2); however, when compared at the species level, site-specific variability was observed. For example, Pocillopora meandrina exhibited the greatest variability, with Kaneohe Bay extracts exhibiting significant activity against only 2 bacteria, as compared to 4 or 5 at the other 2 sites. Montipora capitata extracts from Kaneohe Bay had significant inhibitory or stimulatory activity against all bacteria tested, while those from the other 2 sites were less active. Extracts from Porites lobata from each site significantly inhibited 5 or 6 bacterial strains, but there were site-specific differences against certain bacteria. Differences in levels of antibacterial defense in corals from different sites might offer some explanation of the variable disease levels found among sites in Hawaii. Site-specific variability in chemical defenses may result from a variety of abiotic and biotic factors, such as pathogens (Slattery 1999, Kim et al. 2000b, Dube et al. 2002, Gochfeld et al. 2006), but may also include light (Cronin \& Hay 1996, Slattery \& Paul 2008), desiccation (Cronin \& Hay 1996), temperature (Michalek-Wagner \& Bowden 2000), predation pressure (Swearingen \& Pawlik 1998, Slattery \& Paul 2008), and competition (Turon et al. 1996). This variation may also result from differences in coral-associated microbial communities, which may be related to local environmental factors and to coral stress (Ritchie \& Smith 1995). Colony-level variability in activity was not tested statistically, but was apparent in the relatively large error bars in many of the assays (Fig. 2). Although population-level variability in antibacterial activity of corals has not been examined previously, intercolony variation has been previously recognized (Gunthorpe \& Cameron 1990). Clearly, these patterns warrant further investigation.

Extracts from all 3 coral species were inhibitory to the coral pathogens. The only exception to this was Vibrio shiloi, for which Montipora capitata from Kaneohe Bay and Pocillopora meandrina from Maile Beach stimulated growth and the other extracts had no significant effects (Fig. 2H). Of the pathogens used in this study, only $V$. coralliilyticus is known to affect Indo-Pacific corals, causing coral tissue lysis in P. damicornis from the Red Sea (Ben-Haim et al. 2003). Nonetheless, P. meandrina extracts from 2 of the 3 sites exhibited significant inhibitory effects on the growth of this pathogen (Fig. 2G).

The highest levels of inhibitory activity were against the human enteric bacteria Clostridium perfringens, Serratia marcescens, and Yersinia enterocolitica (Fig. 2B, E,I). These organisms can survive in the ocean, have been isolated from the surfaces of corals, and should 
therefore be considered potential marine pathogens. These bacteria most likely enter the marine environment via sewage (Patterson et al. 2002), and protection from these potential pathogens may be particularly important in near-shore habitats that might be susceptible to leaching or spills. Since coral diseases have been reported more frequently from reefs with higher levels of human activities (Green \& Bruckner 2000, Kaczmarsky et al. 2005, but see Gochfeld et al. 2006), these fecal pathogens may represent risk factors associated with coral disease. Lipp et al. (2002) found C. perfringens and other enteric bacteria within the surface mucus layers of several species of corals in the Florida Keys. C. perfringens has been used as an indicator of sewage pollution in Hawaiian waters (Fujioka 2001), and its nature as a facultative anaerobe suggests that it may be able to survive even in marine sediments. $S$. marcescens is believed to be the etiologic agent for White Pox, a disease that causes considerable mortality in the Caribbean coral Acropora palmata (Patterson et al. 2002). Hawaiian corals are exposed to some of these enteric bacterial strains in situ, as Yersinia sp. was isolated from the surfaces of corals in Kaneohe Bay (Lewis 2005). Of the 3 sites sampled in this study, Kaneohe Bay has a long history of sewage pollution, including chronic historical inputs (Hunter \& Evans 1995) and more recent episodic overflow events. Thus, corals in Kaneohe Bay are more likely to have been exposed to human enteric bacteria than are those at the other 2 sites. Although one might expect that the corals in Kaneohe Bay might therefore be more resistant to those bacteria, this appears to be the case only for Montipora capitata. Overall levels of disease in Kaneohe Bay are comparable to those at other sites in Hawaii, although MWS is more prevalent in Kaneohe Bay than elsewhere (G. Aeby pers. obs.); however, the cause of this disease is not yet known. Both Porites lobata and Pocillopora meandrina from Kaneohe Bay exhibited reduced levels of antibacterial activity overall. Montipora capitata is a common coral on the fringing and patch reefs of south Kaneohe Bay and so is directly exposed to terrestrial run-off and sewage spills. P. lobata and $P$. meandrina, however, are found farther from shore in Kaneohe Bay where they are less exposed to these bacteria and may therefore not have developed defenses against them.

Antibacterial activity also varies by coral condition. When healthy tissues on colonies of Montipora capitata affected by MWS were compared to those from their nearest healthy neighbors (controls), control extracts exhibited significantly greater antibacterial activity against Yersinia enterocolitica, and a similar pattern was seen against 6 other bacterial strains (Fig. 3). Higher levels of antibacterial activity in the control corals may protect them from pathogens and could play a role in keeping these colonies disease-free on a reef with infected neighbors. Within colonies affected by MWS, diseased tissues had significantly greater antibacterial activity against Aurantimonas coralicida, with a similar pattern against 5 other bacterial strains (Fig. 3). Higher levels of antibacterial activity in extracts from diseased tissues could result from inducible defenses (e.g. Karban \& Baldwin 1997) in those tissues in response to pathogen challenge. There is evidence that secondary chemistry changes with colony condition. For example, Dube et al. (2002) and Ward et al. (2007) found induced increases in antifungal activity following inoculation of sea fans with the fungal pathogen Aspergillus sydowii, and Kim et al. (2000b) found elevated levels of antifungal activity in the vicinity of the lesion itself. Alternatively, higher levels of defense in diseased tissues may result from the presence of metabolites produced by the pathogen or other opportunistic microorganisms occupying the diseased tissues. Numerous studies have demonstrated differences in coral-associated microbial communities between healthy and diseased colonies (Ritchie \& Smith 1995, Frias-Lopez et al. 2002, Rohwer et al. 2002). It is not yet clear whether this results when the naturally associated microbial community is compromised (e.g. due to environmental stressors) allowing a pathogen to invade, whether some component of the natural microbial community itself becomes pathogenic, or whether host resistance barriers are penetrated.

Antibacterial chemical defenses are a potentially important mechanism of disease resistance in corals. These defenses appear to be widespread across coral species, but they often act selectively against specific bacterial pathogens (this study). Because of this selectivity, antibacterial activity of a specific extract will depend upon the pathogen being tested. Thus, in order to develop a better understanding of the relationship between chemical defenses and disease, we need to be able to test pathogens relevant to a coral at a particular site. We used a best estimate of ecologically relevant concentrations of extracts in our assays; however, the concentrations used were based on the assumption that chemical constituents in the extracts were produced by the coral itself and that their concentrations were distributed evenly throughout the coral tissue. Although we recognize the limitation of this assumption, chemical ecologists have traditionally used whole-tissue extracts as a starting point until more detailed knowledge of compound localization within the organism becomes available. In addition, lipophilic extracts not tested in the present study may also exhibit antibacterial activity, and represent a future direction in broadening our understanding of coral chemical defenses. Once pathogens associated with disease in Hawaiian corals have been identified, and assuming they can be cultured, assays utilizing those 
bacteria will enable us to identify species, populations, and even colonies exhibiting high levels of antimicrobial activity against those pathogens for use in breeding or transplant programs to aid in reef restoration.

Acknowledgements. We thank F. Stanton, F. Cox, and M. Colvin for help with sample collection, and A. Katzenmeyer, M. S. Bailey, L. Wheeler, K. Davis, and J. Miller for help with sample extractions and bacterial growth assays. S. Threlkeld and A. S. Taylor assisted with statistical analysis. J. B. Olson and M. Slattery provided advice on bioassay development. D. Kutrzeba, S. Ankisetty, H. Kamel, and M. Slattery provided valuable critiques of this manuscript, as did 3 anonymous reviewers. This publication is a result of funding from the National Oceanic and Atmospheric Administration, Center for Sponsored Coastal Ocean Science, under award NA05NOS4261157 to the University of Hawaii for the Hawaii Coral Reef Initiative, with additional support from the National Institute of Undersea Science and Technology under award NA16RU1496. All coral samples were collected under Hawaii Division of Aquatic Resources permit \# 2006-06. This is contribution \# 1319 of the Hawaii Institute of Marine Biology.

\section{LITERATURE CITED}

Aeby GS (2006) Baseline levels of coral disease in the Northwestern Hawaiian Islands. Atoll Res Bull 543:471-488

Barber RT, Hilting AK, Hayes ML (2001) The changing health of coral reefs. Hum Ecol Risk Assess 7:1255-1270

> Ben-Haim Y, Thompson FL, Thompson CC, Cnockaert MC, Hoste B, Swings J, Rosenberg E (2003) Vibrio coralliilyticus sp. nov., a temperature-dependent pathogen of the coral Pocillopora damicornis. Int J Syst Evol Microbiol 53: 309-315

- Cronin G, Hay ME (1996) Susceptibility to herbivores depends on recent history of both plant and animal. Ecology 77:1531-1543

Denner EBM, Smith GW, Busse HJ, Schulmann P and others (2003) Aurantimonas coralicida gen. nov., sp. nov., the causative agent of white plague type II on Caribbean scleractinian corals. Int J Syst Evol Microbiol 53:1115-1122

Dube D, Kim K, Alker AP, Harvell CD (2002) Size structure and geographic variation in chemical resistance of sea fan corals Gorgonia ventalina to a fungal pathogen. Mar Ecol Prog Ser 231:139-150

Ellner SP, Jones LE, Mydlarz LD, Harvell CD (2007) Withinhost disease ecology in the sea fan Gorgonia ventalina: Modeling the spatial immunodynamics of a coral-pathogen interaction. Am Nat 170:E143-E161

Frias-Lopez J, Zerkle AL, Bonheyo GT, Fouke BW (2002) Partitioning of bacterial communities between seawater and healthy, black band diseased and dead coral surfaces. Appl Environ Microbiol 68:2214-2228

Friedlander A, Aeby G, Brown E, Clark A and others (2005) The state of coral reef ecosystems of the main Hawaiian Islands. In: Waddell J (ed) The state of coral reef ecosystems of the United States and Pacific Freely Associated States: 2005. NOAA Technical Memorandum NOS NCCOS 11. NOAA/NCCOS Center for Coastal Monitoring and Assessments Biogeography Team, Silver Spring, MD, p 222-269

Fujioka RS (2001) Monitoring coastal marine waters for sporeforming bacteria of faecal and soil origin to determine point from non-point source pollution. Water Sci Technol 44:181-188
Gochfeld DJ (1991) Energetics of a predator-prey interaction: corals and coral-feeding fishes. Pac Sci 45:246-256

Gochfeld DJ (1997) Mechanisms of coexistence between corals and coral-feeding butterflyfishes. PhD dissertation, University of Hawaii at Manoa

> Gochfeld DJ, Olson JB, Slattery M (2006) Colony versus population variation in susceptibility and resistance to dark spot syndrome in the Caribbean coral Siderastrea siderea. Dis Aquat Org 69:53-65

Green E, Bruckner A (2000) The significance of coral disease epizootiology for coral reef conservation. Biol Conserv 96: 347-361

Gunthorpe L, Cameron AM (1990) Widespread but variable toxicity in scleractinian corals. Toxicon 28:1199-1219

Harvell C, Kim K, Burkholder J, Colwell R and others (1999) Emerging marine diseases-climate links and anthropogenic factors. Science 285:1505-1510

Hunter CL, Evans CW (1995) Coral reefs in Kaneohe Bay, Hawaii: two centuries of western influence and two decades of data. Bull Mar Sci 57:501-515

> Jensen PR, Harvell CD, Wirtz K, Fenical W (1996) Antimicrobial activity of extracts of Caribbean gorgonian corals. Mar Biol 125:411-419

Kaczmarsky LT, Draud M, Williams EH (2005) Is there a relationship between proximity to sewage effluent and the prevalence of coral disease? Caribb J Sci 41:124-137

Karban R, Baldwin IT (1997) Induced responses to herbivory. University of Chicago Press, Chicago, IL

> Kelly SR, Garo E, Jensen PR, Fenical W, Pawlik JR (2005) Effects of Caribbean sponge secondary metabolites on bacterial surface colonization. Aquat Microb Ecol 40:191-203

- Kelman D, Kashman Y, Rosenberg E, Kushmaro A, Loya Y (2006) Antimicrobial activity of Red Sea corals. Mar Biol 149:357-363

Kim K, Kim PD, Alker AP, Harvell CD (2000a) Chemical resistance of gorgonian corals against fungal infections. Mar Biol 137:383-401

Kim K, Harvell CD, Kim PD, Smith GW, Merkel SM (2000b) Fungal disease resistance of Caribbean sea fan corals (Gorgonia spp.). Mar Biol 136:259-267

Koh EGL (1997) Do scleractinian corals engage in chemical warfare against microbes? J Chem Ecol 23:379-398

> Kushmaro A, Banin E, Loya Y, Stackebrandt E, Rosenberg E (2001) Vibrio shiloi sp. nov., the causative agent of bleaching of the coral Oculina patagonica. Int J Syst Evol Microbiol 51:1383-1388

Lewis TD (2005) Coral disease in Hawaii. NOAA Progress Final Report, January 2005 Available at www.hawaii.edu/ ssri/hcri/research/reports/interim/pi/lewis.shtml

Lipp EK, Jarrell JL, Griffin DW, Lukasik J, Jacukiewicz J, Rose JB (2002) Preliminary evidence for human fecal contamination in corals from the Florida Keys, USA. Mar Pollut Bull 44:666-670

> Marquis CP, Baird AH, de Nys R, Holmström C, Koziumi N (2005) An evaluation of the antimicrobial properties of the eggs of 11 species of scleractinian corals. Coral Reefs 24: 248-253

Michalek-Wagner K, Bowden BF (2000) Effects of bleaching on secondary metabolite chemistry of alcyonacean soft corals. J Chem Ecol 26:1543-1562

Mullen KM, Peters EC, Harvell CD (2004) Coral resistance to disease. In: Rosenberg E, Loya Y (eds) Coral health and disease. Springer-Verlag, Berlin, p 377-399

Mydlarz LD, Harvell DC (2007) Peroxidase activity and inducibility in the sea fan coral exposed to a fungal pathogen. Comp Biochem Physiol A 146:54-62

Patterson K, Porter J, Ritchie K, Polson S and others (2002) 
The etiology of white pox, a lethal disease of the Caribbean elkhorn coral, Acropora palmata. Proc Natl Acad Sci USA 99:8725-8730

Ritchie KB (2006) Regulation of microbial populations by coral surface mucus and mucus-associated bacteria. Mar Ecol Prog Ser 322:1-14

Ritchie KB, Smith GW (1995) Carbon-source utilization patterns of coral-associated marine heterotrophs. J Mar Biotechnol 3:105-107

Rohwer F, Breitbart M, Jara J, Azam F, Knowlton N (2001) Diversity of bacteria associated with the Caribbean coral Montastrea franksi. Coral Reefs 20:85-91

Rohwer F, Seguritan V, Azam F, Knowlton N (2002) Diversity and distribution of coral-associated bacteria. Mar Ecol Prog Ser 243:1-10

Rosenberg E, Loya Y (2004) Coral health and disease. Springer-Verlag, Berlin

Slattery M (1999) Fungal pathogenesis of the sea fan Gorgonia ventalina: direct and indirect consequences. Chemoecology 9:97-104

Slattery M, Paul VJ (2008) Indirect effects of bleaching on predator deterrence in the tropical Pacific soft coral Sinularia maxima. Mar Ecol Prog Ser 354:169-179

Editorial responsibility: Joseph Pawlik, Wilmington, North Carolina, USA
Sutherland KP, Porter JW, Torres C (2004) Disease and immunity in Caribbean and Indo-Pacific zooxanthellate corals. Mar Ecol Prog Ser 266:273-302

Swearingen DC III, Pawlik JF (1998) Variability in the chemical defense of the sponge Chondrilla nucula against predatory reef fishes. Mar Biol 131:619-627

Turon X, Becerro MA, Uriz MJ (1996) Seasonal patterns of toxicity in benthic invertebrates: the encrusting sponge Crambe crambe (Poecilosclerida). Oikos 75:33-40

Ward JR, Kim K, Harvell CD (2007) Temperature affects coral disease resistance and pathogen growth. Mar Ecol Prog Ser 329:115-121

Weagant SD, Kaysner CA (1983) Modified enrichment broth for isolation of Yersinia enterocolitica from nonfood sources. Appl Environ Microbiol 45:468-471

Weil E (2004) Coral reef diseases in the wider Caribbean. In: Rosenberg E, Loya Y (eds) Coral health and disease. Springer-Verlag, Berlin, p 35-68

Weil E, Smith G, Gil-Agudelo D (2006) Status and progress in coral reef disease research. Dis Aquat Org 69:1-7

Willis B, Page C, Dinsdale E (2004) Coral disease on the Great Barrier Reef. In: Rosenberg E, Loya Y (eds) Coral health and disease. Springer-Verlag, Berlin, p 69-104

Submitted: August 30, 2007; Accepted: January 24, 2008

Proofs received from author(s): June 14, 2008 